\title{
Ethics
}

International Affairs

VOLUME 34 - NUMBER 4 - WINTER 2020

\section{ROUNDTABLE: International Institutions and Peaceful Change}

Mark Beeson, Toni Erskine, Huiyun Feng, Trine Flockhart, Kai He, David A. Lake, T. V. Paul, Anders Wivel

\section{ES SAYS}

Finding Refuge through Employment: Worker Visas as a Complementary Pathway for Refugee Resettlement

Michael Doyle and Elie Peltz

The United Nations at Seventy-Five: Passing the COVID Test?

Ş. İlgü Özler

\section{REVIEW ESSAY}

International Political Theory 2020: The Worst of Times, the Best of Times Cian O'Driscoll

\section{REVIEWS}

The First Political Order: How Sex Shapes Governance and National Security Worldwide Valerie M. Hudson, Donna Lee Bowen, and Perpetua Lynne Nielsen Review by ShIRLEy Graham

Political Theology of International Order William Bain

REVIEW by AARON MCKeIL

Undocumented Nationals: Between Statelessness and Citizenship

Wendy Hunter

REVIEW by KelLy STAPLES 


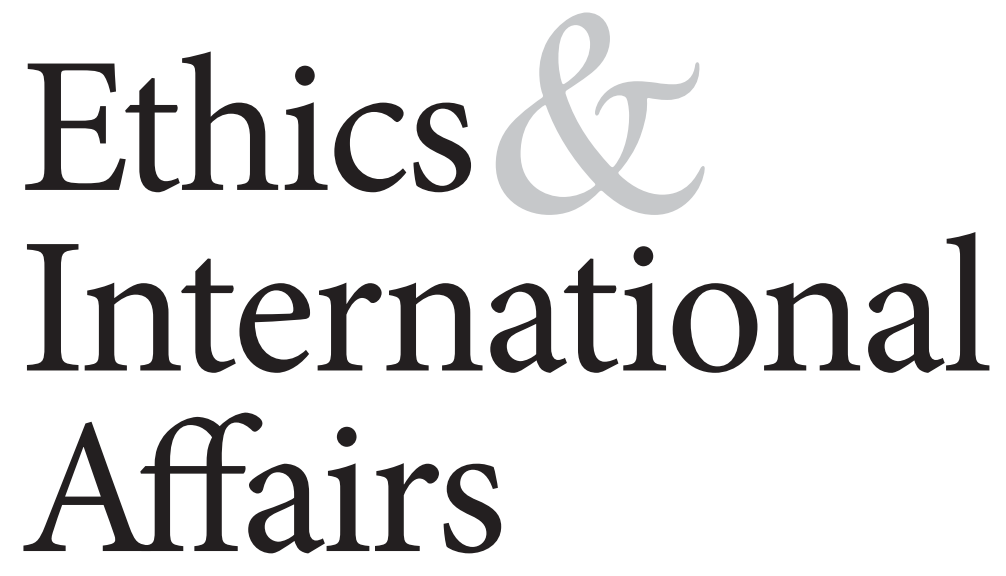

VOLUME $34 \cdot$ NUMBER $4 \cdot$ WINTER 2020 


\section{Ethics \& International Affairs}

THE JOURNAL OF THE CARNEGIE COUNCIL

EDITOR IN CHIEF Joel H. Rosenthal

EDITOR Adam Read-Brown

ASSISTANT EDITOR Priya Chokshi

GUEST EDITORS Kai He, T. V. Paul, and Anders Wivel

EDITORIAL INTERN Daniel Hoffman

COPY EDITOR Jana Weinstein

EDITORIAL ADVISORY BOARD

Christian Barry

Alex J. Bellamy

Daniel Brunstetter

Allen Buchanan

Deen K. Chatterjee

Robyn Eckersley

Toni Erskine

Joy Gordon
Nikolas Gvosdev
Ian Hurd
Anthony F. Lang, Jr.
David Luban
Darrel Moellendorf
Valerie Morkevičius

David Rodin

Jennifer Rubenstein

Henry Shue

Anna Stilz

Jennifer Welsh

Leif Wenar

\section{Carnegie Council for Ethics in International Affairs}

The Carnegie Council for Ethics in International Affairs is an independent, nonpartisan, nonsectarian, tax-exempt organization founded in 1914 by Andrew Carnegie. Since its beginnings, the Carnegie Council has asserted its strong belief that ethics, as informed by the world's principal moral and religious traditions, is an inevitable and integral component of all policy decisions, whether in the realm of economics, politics, or national security. The interrelationship of ethics and foreign policy is thus the unifying theme of all Carnegie Council programs. By promoting a greater understanding of the values and conditions that ensure peaceful relations among nations, the Carnegie Council hopes to contribute to a better life for people everywhere.

\section{BOARD OF TRUSTEES}

Maxmillian Angerholzer III

Kathleen Cheek-Milby

Aine Donovan

Richard A. Edlin

Anthony L. Faillace,

Vice Chairman

Jonathan Gage
Stephen D. Hibbard, Chairman

Haris Hromic, Treasurer

Kristen Edgreen Kaufman

Susan King

Brian Mateo

Robert Perlman
Alexander H. Platt

Joel H. Rosenthal,

President

Ronnie Saha

Robert G. Shaw,

Secretary

HONORARY TRUSTEE Maurice S. Spanbock, Esq. 


\title{
Contents
}

\author{
Contributors 429
}

ESSAYS Finding Refuge through Employment: Worker Visas as a

Complementary Pathway for Refugee Resettlement

Michael Doyle and Elie Peltz 433

The United Nations at Seventy-Five: Passing the COVID Test?

Ş. İlgü Özler 445

ROUNDTABLE: Introduction: International Institutions and Peaceful Change

INTERNATIONAL Kai He, T. V. Paul, and Anders Wivel 457

Whither the Liberal International Order? Authority, Hierarchy, and Institutional Change

David A. Lake 461

Soft Balancing, Institutions, and Peaceful Change

Anders Wivel and T. V. Paul 473

International Institutions, Institutional Balancing, and Peaceful

Order Transition

Kai He and Huiyun Feng 487

Intergovernmental Organizations and the Possibility of Institutional Learning: Self-Reflection and Internal Reform in the Wake of Moral Failure

Toni Erskine 503

The Liberal International Order and Peaceful Change: Spillover and the Importance of Values, Visions, and Passions

Trine Flockhart 521

The Regional Path to Peaceful Change: What the Asian and European Experiences Tell Us

Mark Beeson 535

REVIEW ESSAY International Political Theory 2020: The Worst of Times, the Best of Times

Cian O’Driscoll 547

REVIEWS The First Political Order: How Sex Shapes Governance and National Security Worldwide

Valerie M. Hudson, Donna Lee Bowen, and Perpetua Lynne Nielsen

Review by Shirley Graham 557 


\section{Political Theology of International Order}

William Bain

Review by Aaron McKeil 560

Undocumented Nationals: Between Statelessness and Citizenship Wendy Hunter

Review by Kelly Staples 562

\section{PEER REVIEWERS 2019-2020 Peer Reviewers 565}

\section{SUBMISSIONS Guidelines for Submission 567}

RESOURCES For additional Carnegie Council resources on the topics addressed in these pages, please visit www.eiajournal.org. 
ETHICS \& INTERNATIONAL AFFAIRS (ISSN 0892-6794 print; ISSN 1747-7093 online).

\section{Publisher}

Ethics \& International Affairs is published quarterly by Cambridge University Press, One Liberty Plaza, 2oth floor, New York, NY 10006.

\section{Information for subscribers}

Ethics \& International Affairs is published four times per year, in March, June, September, and December, by Cambridge University Press, One Liberty Plaza, 2oth floor, New York, NY 10006. Periodicals postage rate paid at New York, NY, and at additional mailing offices. POSTMASTER: Send address changes in the USA, Canada, and Mexico to: Ethics \& International Affairs, Cambridge University Press, Journals Fulfillment Department, One Liberty Plaza, 2oth floor, New York, NY 10006. Send address changes elsewhere to Ethics \& International Affairs, Cambridge University Press, Journals Fulfillment Department, UPH, Shaftesbury Road, Cambridge $\mathrm{CB}_{2}$ 8BS, England. Institutional subscription prices for 2019 are: Print \& Online: US $\$ 620$ in the USA, Canada, and Mexico; UK $\mathfrak{E}_{3} 81+$ VAT elsewhere. Institutions electronic only: US\$554 in the USA, Canada, and Mexico; UK£ $338+$ VAT elsewhere. Individuals print only: US $\$ 48$ in the USA, Canada, and Mexico; UK£ 32 + VAT elsewhere. The price includes online access to the current and all online back files to January 1st 1997, where available.

\section{Delivery Terms and Legal Title}

Prices include delivery of print journals to the recipient's address. Delivery terms are Delivered Duty Unpaid (DDU); the recipient is responsible for paying any import duty or taxes. Legal title passes to the customer on despatch by our distributors.

Production Editor: Katrina Swartz (email: kswartz@cambridge.org).

Electronic Access Access to this journal is available free online within institutions in the developing world through the AGORA initiative with the FAO, the HINARI initiative with the WHO and the OARE initiative with UNEP. For information, visit www.aginternetwork.org, www.healthinternetwork.org, www.oarescience.org. Abstracting and Indexing Services The Journal is indexed by Academic Search (EBSCO), Academic Search Premier (EBSCO), CSA Environmental Sciences \& Pollution Management Database (CSA/CIG), CSA Sustainability Science Abstracts (CSA/CIG), Current Abstracts (EBSCO), Current Contents $\%$ Social and Behavioral Sciences (Thomson Reuters), Expanded Academic ASAP (Thomson Gale), IBSS: International Bibliography of the Social Sciences (LSE), InfoTrac, International Political Science Abstracts (IPSA), Journal Citation Reports/ Social Sciences Edition (Thomson Reuters), OMNIFILE Full Text Mega Edition (OMNIFILE), PAIS: Public Affairs Information Service (CSA/CIG), Proquest 5000 (ProQuest), Proquest Discovery (ProQuest), Proquest Platinum (ProQuest), Proquest Research Library (ProQuest), Proquest Social Science Journals (ProQuest), Social Sciences Citation Index ${ }^{\infty}$ (Thomson Reuters), Social Sciences Index/Abstracts (HW Wilson), Student Resource Center College (w/ Academic ASAP),Wilson OMNIFILE Full Text Select (HW Wilson) and Worldwide Political Sciences Abstracts (CSA/CIG).

Disclaimer The Publisher, Carnegie Council, and Editors cannot be held responsible for errors or any consequences arising from the use of information contained in this journal; the views and opinions expressed do not necessarily reflect those of the Publisher, Council and Editors, neither does the publication of advertisements constitute any endorsement by the Publisher, Council and Editors of the products advertised.

Copyright and Photocopying Copyright (C) 2020 Carnegie Council for Ethics in International Affairs. All rights reserved. No part of this publication may be reproduced, in any form or by any means, electronic, photocopying, or otherwise, without permission in writing from Cambridge University Press. Policies, request forms, and contacts are available at: http://www.cambridge.org/rights/permissions/permission.htm Permission to copy (for users in the U.S.A.) is available from Copyright Clearance Center, http://www.copyright.com, email: info@copyright.com.

Printed in USA by The Sheridan Press.

View this journal online at journals.cambridge.org/EIA.

ISSN 0892-6794 (Print)

ISSN 1747-7093 (Online) 


\section{Ethics \& International Affairs}

